\title{
A stage-structured model to predict the effect of temperature and salinity on glass eel Anguilla anguilla pigmentation development
}

\author{
C. Briand*†, D. Fatin*, E. Ciccottit and P. Lambert§ \\ *Institution d'Aménagement de la Vilaine, 56130 La Roche-Bernard, France, \\ $\$$ Dipartimento di Biologia, Università degli Studi "Tor Vergata", Via della Ricerca \\ Scientifica, 00133 Rome, Italy and §CEMAGREF, Unité Ressources Aquatiques \\ Continentales, F-33612 Cestas Cedex, France
}

(Received 2 August 2004, Accepted 7 April 2005)

\begin{abstract}
The pigmentation development process of glass eels Anguilla anguilla from stage $\mathrm{V}_{\mathrm{B}}$ to $\mathrm{VI}_{\mathrm{A} 3}$ was modelled by gamma cumulative functions. These functions varied with respect to the factors temperature and salinity whose effects were adjusted by beta functions. Temperature was shown to accelerate pigmentation, while salinity acted as a secondary factor slowing down the pigmentation. The model fits the development of 15 samples kept at various temperatures and salinities in the Vilaine River, as well as samples monitored at other dates and places in Europe. It allows the prediction of the duration of estuarine residency for glass eels, in winter and spring, in the Atlantic estuaries.

C 2005 The Fisheries Society of the British Isles
\end{abstract}

Key words: Anguilla anguilla; European eel; glass eel; pigment stage; salinity; temperature.

\section{INTRODUCTION}

Metamorphosis from the larval to the juvenile stage in fishes involves important morphological, ecological and physiological changes, more evident in those teleosts that show pelagic larvae $v$. benthic adults. Such is the case of the anguillids, whose larva is the leptocephalus, a distinctive long-lived larval stage well adapted to the pelagic life in the ocean (Hulet, 1978; Hulet \& Robins, 1989), that shows a unique developmental strategy among teleosts, with regards to its metabolic rate, growth and osmoregulation (Bishop et al., 2000; Bishop \& Torres, 2001).

During metamorphosis, leptocephali decrease in size and wet mass as the internal gelatinous matrix is degraded and replaced by developing muscles and bones (Kawakami et al., 1999; Pfeiler, 1999). The willow leaf-like shaped larvae begin to acquire the eel like shape and most structures such as the gut, skin, gill and kidney become more developed during this transition from the larval stage to the adult-like glass eel stage (Hulet \& Robins, 1989).

†Author to whom correspondence should be addressed. Tel.: +3329990 8844; fax: +3329990 8849; email: cedric.briand@lavilaine.com 
The progressive pigmentation of skin and internal tissues is also concentrated during metamorphosis from fully-grown larvae to the juvenile phase (Hulet \& Robins, 1989; Tsukamoto, 1990) and the larvae progressively loose their typical fully transparent bodies (Schmidt, 1909; Robins, 1989; Smith, 1989) with only scattered melanophores (Castle, 1997). In the genus Anguilla, this most visible marker has, therefore, supported the stage classification of the metamorphosis process from leptocephalus (stages I-IV) to the glass eel (stages V and VI), corresponding to the reaching of the eel-like body form (Tesch, 2003). The glass eel to elver phase covers stages $V_{A}$ with no pigmentation except a spot on the caudal fin, $\mathrm{V}_{\mathrm{B}}$ with the early development of the pigmentation on the skull and $\mathrm{VI}_{\mathrm{A} 0}$ with development of pigmentation along the base of dorsal fin, and with the first pigment cells beyond the skull spot (Bertin, 1951; Elie et al., 1982). The next stages $\mathrm{VI}_{\mathrm{A} 1}, \mathrm{VI}_{\mathrm{A} 2}, \mathrm{VI}_{\mathrm{A} 3}, \mathrm{VI}_{\mathrm{A} 4}$ and $\mathrm{VI}_{\mathrm{B}}$ (Strubberg, 1913; Bertin, 1951; Elie, 1979; Elie et al., 1982) are based on development of surface and branchiostegal pigmentation.

Together with these morphological changes, catadromous eels of the genus Anguilla perform a remarkable migration from their spawning areas in the ocean drifting to continental areas, where they recruit to freshwater habitats. In particular, Anguilla anguilla (L.) are thought to spawn panmictically in subtropical waters of the Atlantic Ocean, in the Sargasso Sea with their larval migration route from the centre of the spawning ground to the European and North African coasts extending for $>6000 \mathrm{~km}$.

It is thought today that metamorphosis onset occurs between stage I and II, the first morphological modifications (Cieri, 1999) coinciding with the moment when leptocephali reach the continental slope (Tesch, 1980), and its end occurs at stage $\mathrm{VI}_{\mathrm{B}}$ when glass eels have achieved their estuarine migration and juvenile growth begins (Lecomte-Finiger, 1983; Jegstrup \& Rosenkilde, 2003).

An important contribution to the understanding of the larval history of glass eels has been given by the interpretation of otolith microstructure, that provides a precise description of the migration timing from the ocean to the rivers (Tzeng \& Tsai, 1994; Martin, 1995; Arai et al., 1997; De Casamajor et al., 2003), as well as an ecological interpretation of the transition between sea and estuary in the course of the ascent season (De Casamajor et al., 2001a). Recruitment, besides occurring in a changing environment such as the estuary, corresponds to several behavioural changes, that include a shift from pelagic to benthic habits and a shift from vertical movements related to the use of selective tidal stream transport (McCleave \& Wippelhauser, 1987) to an active counter current migration (Creutzberg, 1958). At the anatomical level, this transition brings about morphological and physiological modifications, that occur simultaneously with the development of organs associated with the achievement of metamorphosis (Hulet \& Robins, 1989).

Osmoregulation compensative mechanisms occurs as consequence of the transition from a hypertonic to a hypotonic medium (Ciccotti et al., 1993; Birrell et al., 2000). Swimbladder activation (Hickman, 1981) is related to the change in the migration mechanism. Overall completion of metamorphosis includes pigmentation (Panu, 1929a; Pankhurst, 1983), which is the only visually obvious process allowing the discrete description of a continuous irreversible change. Therefore, if at the individual level it provides an indication of the amount of 
time spent since the pigment process was triggered, at the population level the stage classification has often supported many geographical and seasonal descriptions of the coastal and estuarine recruitment process, for several species of the genus Anguilla (Elie, 1979; Cantrelle, 1981; Charlon \& Blanc, 1982; Haro \& Krueger, 1988; Boëtius \& Boëtius, 1989; De Casamajor, 1998; Jellyman et al., 1999).

The spatial or temporal comparisons of samples and the ecological interpretation of the time and space migration dynamics as inferred from pigment stages composition, however, are not straightforward. In fact, several uncertainties such as the individual variability of the metamorphosis, the variation in stage duration and most of all, the influence of environmental factors on the pigmentation process limits the ecological interpretations derived from pigment stages (Strubberg, 1913; Lecomte-Finiger, 1983; Tsukamoto, 1990; Ciccotti et al., 1993; Dou et al., 2003).

Recently, both salinity and temperature, key variables in estuaries during glass eels ascent, were confirmed to be factors influencing the development of pigmentation, and their role was described, while the experimental handling process was shown not to influence the pigmentation process (Briand et al., 2004). Based on these results and some additional experiments, the objectives of this study were to: (1) propose a model describing the evolution of pigment stages with reference to temperature and salinity, (2) test the predictive model for glass eel pigment stages in other experiments and (3) discuss the applications for this model, in the general objective of providing a tool for the understanding and description of spatial and temporal dynamics of glass eels recruitment in estuarine systems.

\section{MATERIALS AND METHODS}

\section{EXPERIMENTAL PLAN}

Fifteen samples of glass eels were collected using commercial fishing boats in the Vilaine Estuary, during and after the commercial fishing season in 2000 and 2001 (see Table I for sample collection dates). Two glass eel samples were maintained in situ in the estuary, in fresh water upstream of the Arzal Dam $\left(F_{1}\right.$ to $\left.F_{6}\right)$ and downstream of the dam $\left(E_{2}\right.$ to $\left.E_{6}\right)$ respectively, in cages of $2 \mathrm{~mm}$ mesh-size held $1 \mathrm{~m}$ from the bottom with a rope (Briand et al., 2004). Four samples $\left(\mathrm{R}_{1}\right.$ to $\left.\mathrm{R}_{4}\right)$, collected in 2001 , were maintained in laboratory conditions, i.e. kept in the refrigerator in the dark. These additional experiments were necessary to force the model to express positive values at low temperatures and thus describe conditions encountered in French estuaries in January and February. Temperature was recorded every $6 \mathrm{~min}$ with probes in each site, and varied from 4.8 to $19 \cdot 1^{\circ} \mathrm{C}$ in fresh water, $5 \cdot 4$ to $20 \cdot 1^{\circ} \mathrm{C}$ in the estuary, and from 0.4 to $4.9^{\circ} \mathrm{C}$ in the laboratory. The salinity was recorded close to the cages three times a week. Salinity was zero in fresh water and varied cyclically according to the discharge and tide from $0 \cdot 1$ to $29 \cdot 2$ in the estuary. The salinity was kept constant in the laboratory from 0 to $26 \cdot 6$ (Table I).

\section{SAMPLE EXAMINATION}

The samples were examined three times a week for pigment developmental stages. All glass eels were retrieved from each lot and anaesthetized with phenoxy ethanol at a concentration of $1 \%$. About 70 glass eels were collected randomly from each lot, and 


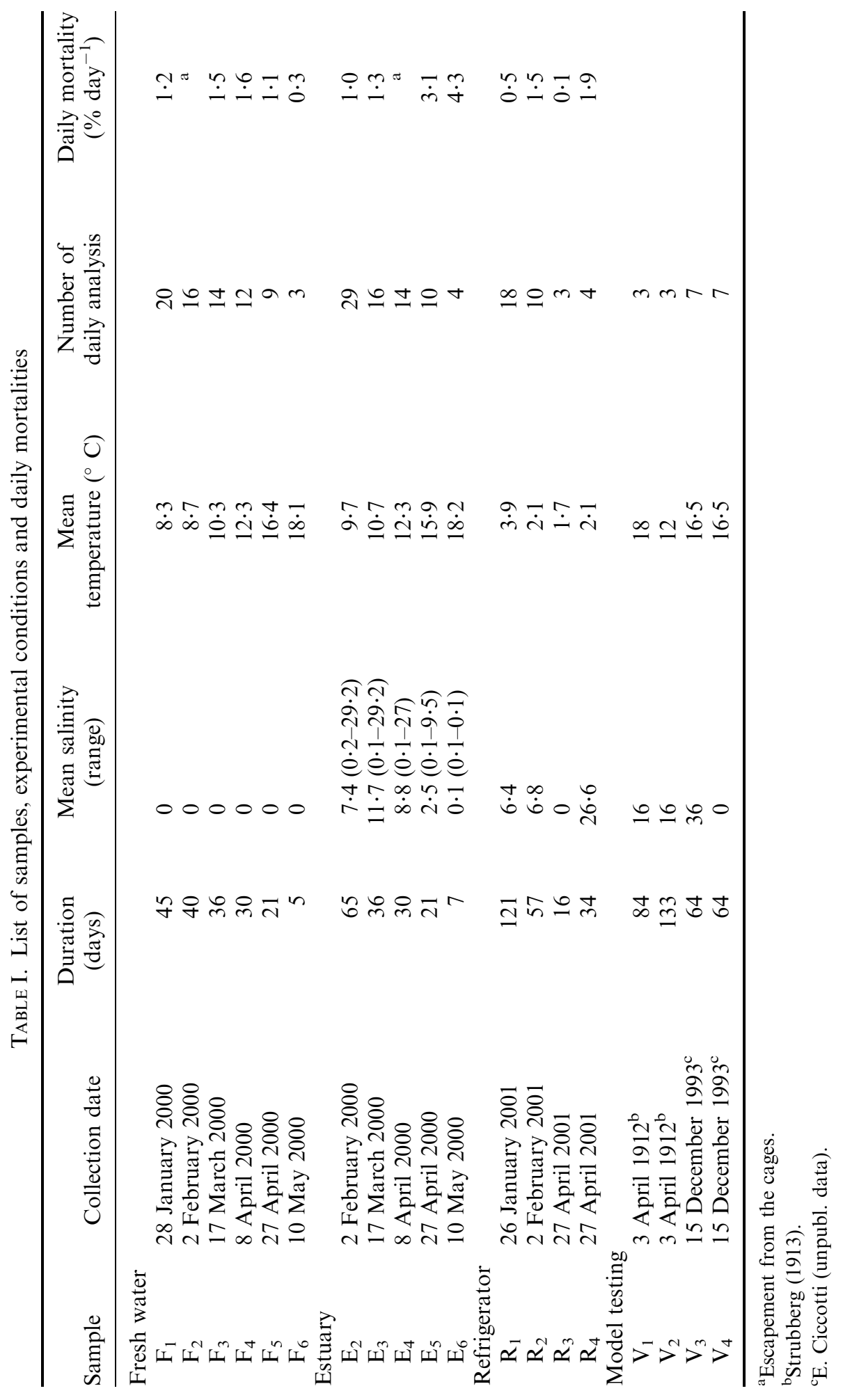


reintroduced after pigmentation examination. Epidermal pigmentation was assessed according to the sequence defined by Elie et al. (1982). This classification, that defines seven stages, was chosen in relation to the fact that it reviews preceding classifications, in particular Strubberg (1913) that considers six stages. The experiments were progressively stopped when stages $\mathrm{VI}_{\mathrm{A} 2}$ and $\mathrm{VI}_{\mathrm{A} 3}$ represented $>80 \%$ of the proportion of all the stages. The pigment stages observed during the study were $\mathrm{V}_{\mathrm{B}}$ to $\mathrm{VI}_{\mathrm{A} 3}$. As the stages $\mathrm{VI}_{\mathrm{A} 4}$ were rare $(<1 \%)$ they were included in the $\mathrm{VI}_{\mathrm{A} 3}$ counts.

Mortality was evaluated at the end of the trial for each experimental batch. Daily mortality was calculated as the total mortality during the experiment, divided by the duration of the experiment.

\section{MODELLING}

The modelling of pigmentation process was based on stage transition models. The series of pigment stages obtained for each sample was transformed to calculate the cumulative percentage of glass eels having reached a particular stage over time. The progressive ageing was then simulated for $\mathrm{VI}_{\mathrm{A} 0 \text { cum }}$ to $\mathrm{VI}_{\mathrm{A} 3}$ cum by a gamma cumulated distribution function $(\mathrm{G})$ whose scale parameter was set to 1 for all cumulated stages (Manly, 1990). Four parameters of shape $\left(p_{1}, \ldots, p_{4}\right)$ were thus fitted: $V_{A 0 \text { cum }}=G\left(\varphi ; p_{1}, 1\right)$, $\mathrm{VI}_{\mathrm{A} 1 \text { cum }}=\mathrm{G}\left(\varphi ; \mathrm{p}_{2}, 1\right), \mathrm{VI}_{\mathrm{A} 2 \text { cum }}=\mathrm{G}\left(\varphi ; \mathrm{p}_{3}, 1\right)$ and $\mathrm{VI}_{\mathrm{A} 3 \text { cum }}=\mathrm{G}\left(\varphi ; \mathrm{p}_{4}, 1\right)$. The duration of one pigment stage was therefore considered as a random variable following a gamma function.

The variable $\varphi$, 'pigmentation time', was calculated as the cumulative sum from the beginning of the experiment of the days corrected with the product of an efficient daily temperature and an efficient daily salinity. The practical meaning of this formulation can be explained as follows: daily salinities and temperatures fully relevant for the pigmentation process would correspond to efficient daily temperatures and efficient daily salinities equal to 1 and each day would contribute for 1 to the pigmentation time. When salinity or temperature conditions are less favourable, the efficient daily salinity or the efficient daily temperature are lower than 1 and one day counts for $<1$ for the pigmentation time. The choice of a product expresses the interacting effect of each factor on the pigmentation process. The physiological optimum for growth is found at $22-23^{\circ} \mathrm{C}$ for yellow eels (Sadler, 1979) and glass eels (Elie \& Daguzan, 1976). This optimum in growth could also apply for other morphological development such as pigmentation. As the range of temperatures explored in the experiments $\left(0 \cdot 5-20^{\circ} \mathrm{C}\right)$ was below this optimum, beta cumulative distribution curves were chosen for both temperature and salinity to allow the expression of a wide variety of asymmetrical sigmoid responses. Limits of this beta curve were set out of the range of experimental temperatures and salinities, to ensure that the lack of flexibility of beta curves near their boundaries did not bias the model. Therefore, the 'efficient daily temperature' $\mathrm{T}_{\mathrm{eff}}\left(\theta_{\mathrm{i}} ; \mathrm{p}_{5}, \mathrm{p}_{6}\right)$ was calculated from daily temperatures with a beta cumulative distribution function of boundaries 0 and 30. The efficient daily salinity $S_{\text {eff }}\left(\sigma_{i} ; p_{7}, p_{8}\right)$ was calculated from average salinity with a (1-beta) cumulative distribution function of boundaries of 5 and $40 \%$.

As pigment stages differed between samples at the beginning of the experiment, the pigmentation time of each sample was corrected by adding an initial pigmentation time $\varphi_{0}$, that was calculated as the mean of inverse gamma functions for stages $\mathrm{VI}_{\mathrm{A} 0}$ cum to $\mathrm{VI}_{\mathrm{A} 3 \text { cum }}$ calculated with parameters $\left(\mathrm{p}_{1}\right.$ to $\left.\mathrm{p}_{4}\right)$ from the initial pigment stages composition of the sample.

Model fitting was performed by minimization of the square distance between experimental and modelled data (function lsqcurvefit of Matlab). The performance of the whole model, and each sample, was determined by $R^{2}$ and mean absolute errors.

\section{MODEL VALIDATION}

The model prediction was then tested against other laboratory experiments, carried out by other authors and selected because they had detailed records of salinities and 
temperatures, whose range was within the range tested in the model. Experiments $V_{1}$ and $\mathrm{V}_{2}$ were drawn from Strubberg's (1913) experiment. He kept samples of glass eels in aquaria in the laboratory and a cellar and provided detailed account of temperature, salinity and evolution of pigment stages as summarized in Table 1. As temperatures were not provided from 83 to 133 days for the laboratory experiment, a $100 \% \mathrm{VI}_{\mathrm{A} 3}$, the final composition of the sample, was considered as already reached after 83 days.

The model was based solely on $\mathrm{VI}_{\mathrm{A} 1}$ and $\mathrm{VI}_{\mathrm{A} 3}$ cumulated data, because the stage $\mathrm{VI}_{\mathrm{A} 1}$, proposed by Elie et al. (1982), groups the $\mathrm{VI}_{\mathrm{A} 1}, \mathrm{VI}_{\mathrm{A} 2-1}$ and $\mathrm{VI}_{\mathrm{A} 2-2}$ pigment stages described by Strubberg (1913).

Samples $\mathrm{V}_{3}$ and $\mathrm{V}_{4}$ were based on a laboratory trial carried out with glass eels collected during their ascent in December 1994 at the mouth of the River Tiber (Central Italy) and kept for 60 days at controlled temperatures 16.5 and $21^{\circ} \mathrm{C}$, and at salinities 0 and 35 (E. Ciccotti, unpubl. data). Samples were examined for pigmentation at 3 and 7 days from acclimation and then at 14 days intervals up to the end of the experiment, following anaesthesia. In this trial, Boëtius's (1976) classification of five stages (A-E) was used, therefore data were converted to Elie et al.'s (1982) classification as following $A=V_{B}$, $\mathrm{B}=\mathrm{VI}_{\mathrm{A} 0}+\mathrm{VI}_{\mathrm{A} 1}, \mathrm{C}=\mathrm{VI}_{\mathrm{A} 2}+\mathrm{VI}_{\mathrm{A} 3}$ and $\mathrm{D}=\mathrm{VI}_{\mathrm{A} 4}$.

\section{STAGE DURATION DERIVED FROM THE MODEL}

In stage transition models, the use of a gamma distribution implies that the mean time of entry to a stage is equal to the parameter $p$ value (Manly, 1990). As in the present model, this mean time of entry was not related to a duration but rather to the 'pigmentation time', the duration of each pigment stage was converted into days from the ratio between $\mathrm{p}$ values $(\varphi)$ for each stage and daily pigmentation time $\left(\varphi\right.$ day $\left.^{-1}\right)$ calculated from constant values of temperature and salinity.

\section{RESULTS}

\section{IN SITU EXPERIMENTS}

In fresh water and the estuary, the pigment stages evolved from $83 \%$ (range $49-99 \%$ ) of glass eel stages $\mathrm{V}_{\mathrm{B}}$ and $\mathrm{V}_{\text {IA0 }}$ at the beginning, to $0 \cdot 5 \%$ (range 0 $2 \cdot 9 \%$ ) at the end (Table II). The duration of the experiments shortened from 40 to 65 days for the samples collected in January and February to 21-36 days for those collected in March and April and was finally reduced to 5 to 7 days for the last experiments in May. This reduction was the consequence of the shift in initial stage composition $\left(\chi^{2}\right.$, d.f. $\left.=20, P<0 \cdot 001\right)$, with more advanced stages at the end of the season (Table II). It was also correlated with the increase in water temperature from $8 \cdot 3$ to $18 \cdot 2^{\circ} \mathrm{C}(r=-0 \cdot 86, P<0 \cdot 001)$.

\section{LABORATORY EXPERIMENTS}

In the laboratory samples, the pigment stages evolved from 52\% (range 14 $90 \%$ ) of $\mathrm{V}_{\mathrm{B}}-\mathrm{VI}_{\mathrm{A} 0}$ at the beginning of the experiments, to $28 \%$ (range $4-81 \%$ ) at the end. Due to high mortalities, the experiments started in January and February were ended after 121 and 57 days, before stages $\mathrm{VI}_{\mathrm{A} 2}$ and $\mathrm{VI}_{\mathrm{A} 3}$ reached $80 \%$ of the total sample. The last two samples had shorter durations and were 
TABLE II. Initial and final pigment stages detailed distributions for in situ experiments used in the model (see Table I for samples)

\begin{tabular}{|c|c|c|c|c|c|c|}
\hline & \multirow[b]{2}{*}{ Sample } & \multicolumn{5}{|c|}{ Stages $\% *$} \\
\hline & & $\mathrm{V}_{\mathrm{B}}$ & $\mathrm{VI}_{\mathrm{A} 0}$ & $\mathrm{VI}_{\mathrm{A} 1}$ & $\mathrm{VI}_{\mathrm{A} 2}$ & $\mathrm{VI}_{\mathrm{A} 3}$ \\
\hline \multicolumn{7}{|c|}{ Fresh water } \\
\hline \multirow[t]{2}{*}{ F1 } & Start & 34 & 64 & 0 & 2 & 0 \\
\hline & End & 0 & 1 & 9 & 66 & 24 \\
\hline \multirow[t]{2}{*}{$\mathrm{F} 2$} & Start & 40 & 49 & 10 & 1 & 0 \\
\hline & End & 0 & 0 & 6 & 63 & 31 \\
\hline \multirow[t]{2}{*}{ F3 } & Start & 17 & 72 & 8 & 3 & 0 \\
\hline & End & 0 & 0 & 0 & 33 & 67 \\
\hline \multirow[t]{2}{*}{$\mathrm{F} 4$} & Start & 21 & 74 & 2 & 1 & 2 \\
\hline & End & 0 & 1 & 5 & 31 & 63 \\
\hline \multirow[t]{2}{*}{ F5 } & Start & 11 & 73 & 12 & 3 & 1 \\
\hline & End & 0 & 0 & 4 & 37 & 59 \\
\hline \multirow[t]{2}{*}{ F6 } & Start & 5 & 44 & 11 & 31 & 9 \\
\hline & End & 0 & 0 & 8 & 46 & 46 \\
\hline \multicolumn{7}{|c|}{ Estuary } \\
\hline \multirow[t]{2}{*}{ E2 } & Start & 40 & 49 & 10 & 1 & 0 \\
\hline & End & 0 & 0 & 6 & 27 & 67 \\
\hline \multirow[t]{2}{*}{ E3 } & Start & 24 & 64 & 8 & 4 & 0 \\
\hline & End & 0 & 0 & 7 & 36 & 57 \\
\hline \multirow[t]{2}{*}{ E4 } & Start & 13 & 82 & 2 & 1 & 2 \\
\hline & End & 0 & 3 & 9 & 29 & 59 \\
\hline \multirow[t]{2}{*}{ E5 } & Start & 2 & 82 & 12 & 3 & 1 \\
\hline & End & 0 & 0 & 3 & 35 & 62 \\
\hline \multirow[t]{2}{*}{ E6 } & Start & 0 & 49 & 11 & 31 & 9 \\
\hline & End & 0 & 0 & 8 & 50 & 42 \\
\hline \multicolumn{7}{|c|}{ Refrigerator } \\
\hline \multirow[t]{2}{*}{ R1 } & Start & 30 & 59 & 10 & 1 & 0 \\
\hline & End & 2 & 15 & 46 & 37 & 0 \\
\hline \multirow[t]{2}{*}{$\mathrm{R} 2$} & Start & 81 & 9 & 9 & 1 & 0 \\
\hline & End & 50 & 31 & 19 & 0 & 0 \\
\hline \multirow[t]{2}{*}{ R3 } & Start & 7 & 7 & 27 & 27 & 32 \\
\hline & End & 3 & 0 & 35 & 44 & 18 \\
\hline \multirow[t]{2}{*}{$\mathrm{R} 4$} & Start & 7 & 7 & 27 & 27 & 32 \\
\hline & End & 0 & 9 & 24 & 50 & 17 \\
\hline
\end{tabular}

*Stages correspond to the pigmentation sequence defined by Elie et al. (1982).

composed of $>90 \%$ of $\mathrm{VI}_{\mathrm{A} 1}-\mathrm{VI}_{\mathrm{A} 3}$ stages in 16 days in fresh water and 34 days in the estuary (Tables I and II).

\section{MORTALITY}

The samples comprised 100 to 279 glass eels at the beginning of the experiment, and 32 to $159($ mean $=70)$ at the end. The daily mortality varied from $0 \cdot 3$ to $4 \cdot 3 \%$ day $^{-1}$ in the cages and $0 \cdot 1$ to $1 \cdot 9 \%$ day $^{-1}$ in the refrigerator. The largest mortalities occurred in estuary during the flood period and concerned the samples $\mathrm{E}_{5}$ and $\mathrm{E}_{6}$ (Table I). 


\section{MODELLING}

A common model for all experiments provided a good fit of 728 points corresponding to the results of 11678 glass eels distributed in 15 experiments (Fig. 1). Splitting into locations, the model was adjusted on 296, 292 and 140 points, corresponding to the repartition in four cumulated stages of 4969,4566 and 2143 glass eels, analysed on 74, 73 and 35 occasions for the freshwater, estuary and laboratory samples respectively.

The $R^{2}$ between observed and simulated data was 0.93 . It varied from 0.87 to 0.96 among samples. It was similar for fresh water (range 0.87-0.96) and the estuary (range 0.87-0.95) and was higher for the laboratory (range 0.93-0.96). The model mean absolute error was $7 \%$, varying from 5 to $9 \%$ among samples, 6 to $9 \%$ for in situ samples and 5 to $7 \%$ for laboratory samples. From $\mathrm{VI}_{\mathrm{A} 0 \text { cum }}$ to

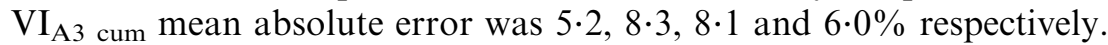

The parameters of the model allowed the description of stage durations with parameters $\mathrm{p}_{1}$ to $\mathrm{p}_{4}$ being the mean pigmentation time necessary for passage from stage $\mathrm{V}_{\mathrm{B}}$ to stages $\mathrm{VI}_{\mathrm{A} 0}$ to $\mathrm{VI}_{\mathrm{A} 3}$ [Fig. 2(a)]. The parameters values and their range were fitted as following: $\mathrm{p}_{1}=0.267(0.204-0.331), \mathrm{p}_{2}=0.835(0.680$ $0.991), \mathrm{p}_{3}=1.560(1.302-1 \cdot 819)$ and $\mathrm{p}_{4}=3.682(3 \cdot 168-4 \cdot 195)$. The notion of 'pigmentation time' allowed the use of the same model in experiments whose durations varied from 6 days to 3 months. The pigmentation time was fitted on both temperature and salinity, with temperature being the main factor and salinity acting as a secondary factor slowing down the pigmentation (Fig. 2(b)]. Parameters $\mathrm{p}_{5}$ and $\mathrm{p}_{6}$ corresponding to 'efficient daily temperature' were calculated as $\mathrm{p}_{5}=4 \cdot 566(3 \cdot 808-5 \cdot 324)$ and $\mathrm{p}_{6}=8 \cdot 141(6 \cdot 043-10 \cdot 239)$.
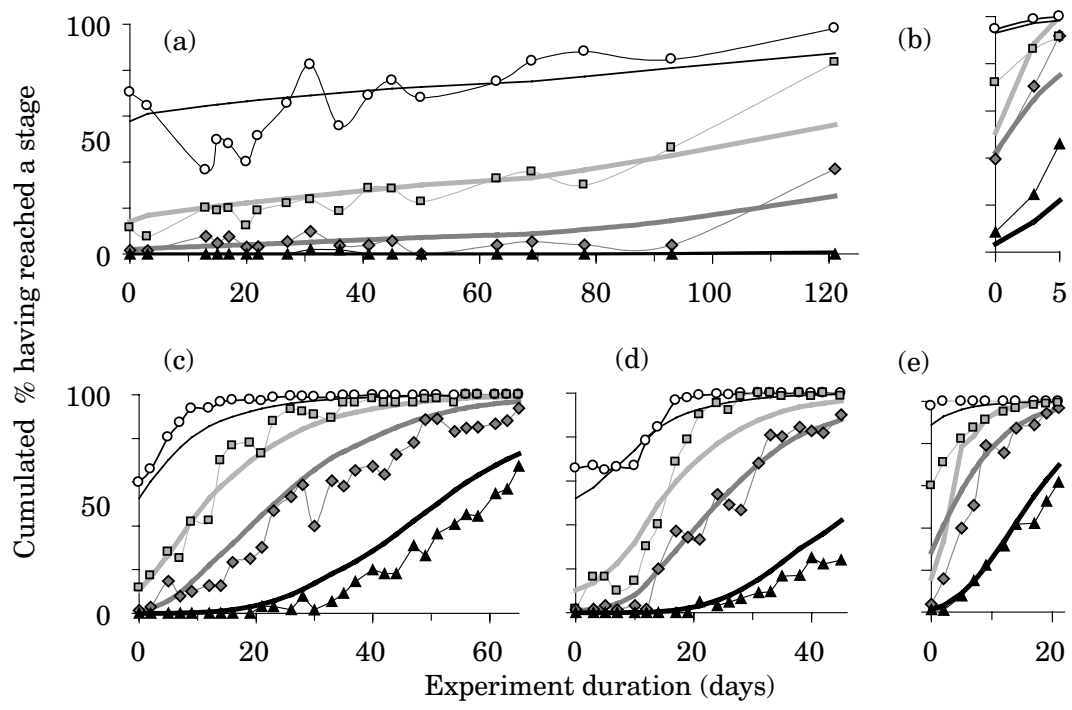

(e)

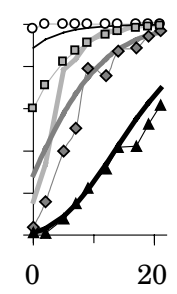

FIG. 1. Calibration of the model illustrated on five samples, for observed (-○-) and modelled (-) cumulative distributions, i.e. cumulative percentage of glass eels having reached particular stage over time for stages $\mathrm{VI}_{\mathrm{A} 0}(-; \bigcirc), \mathrm{VI}_{\mathrm{A} 1}(-; \square), \mathrm{VI}_{\mathrm{A} 2}(-; \diamond)$ and $\mathrm{VI}_{\mathrm{A} 3}(-; \boldsymbol{\Delta})$. Experiments in (a) refrigerator $\left(\mathrm{R}_{1} ; 3 \cdot 9^{\circ} \mathrm{C}\right.$, salinity $\left.6 \cdot 4\right)$, (b) fresh water $\left(\mathrm{F}_{6} ; 18 \cdot 1^{\circ} \mathrm{C}\right.$, salinity $\left.0 \cdot 0\right)$, (c) estuary $\left(\mathrm{E}_{2}\right.$; $9 \cdot 7^{\circ} \mathrm{C}$, salinity $\left.7 \cdot 4\right)$, (d) fresh water $\left(\mathrm{F}_{1} ; 8 \cdot 3^{\circ} \mathrm{C}\right.$, salinity $\left.0 \cdot 0\right)$ and estuary $(\mathrm{e})\left(\mathrm{E}_{5} ; 15 \cdot 9^{\circ} \mathrm{C}\right.$, salinity $2 \cdot 5)$. 

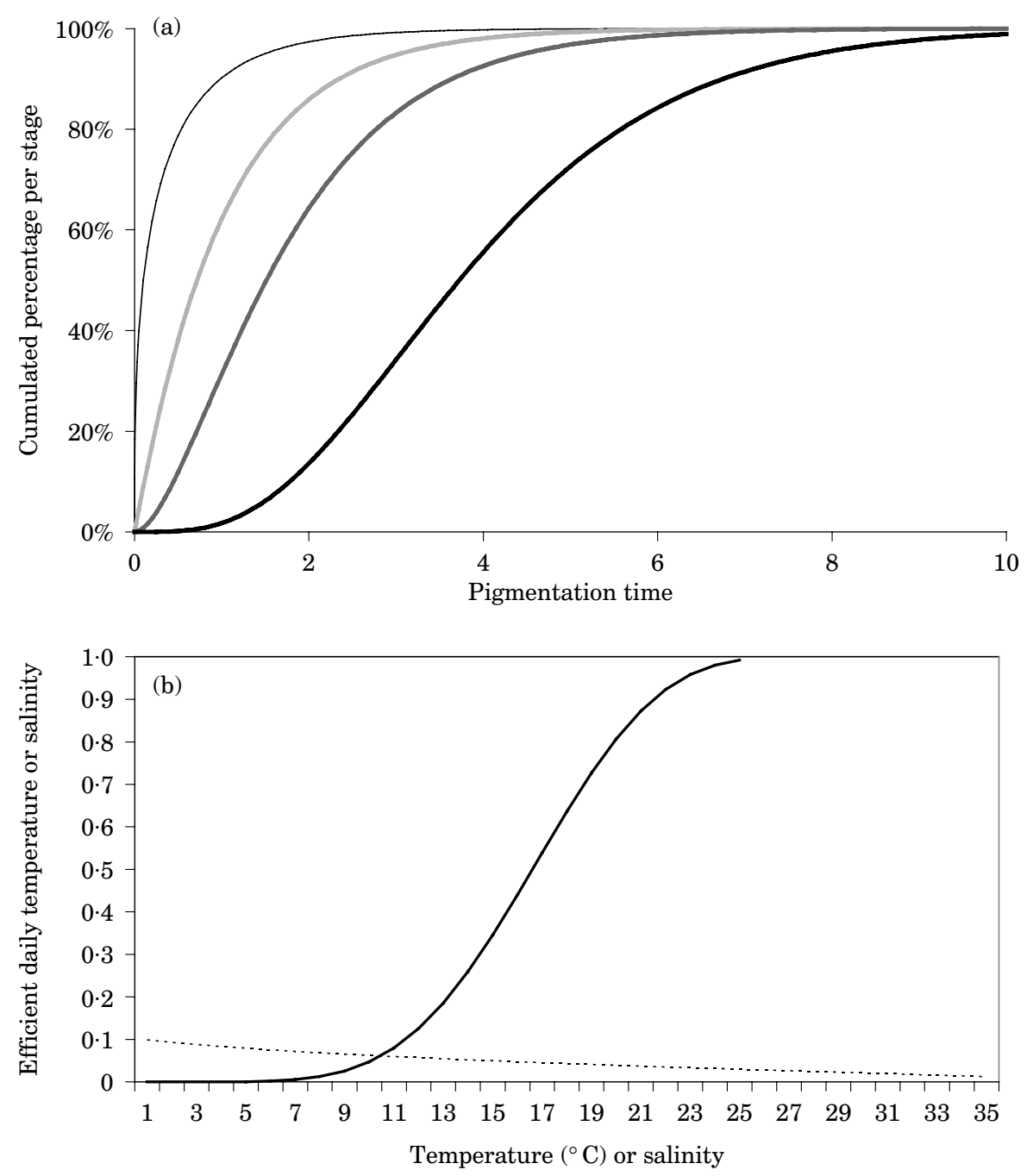

FIG. 2. (a) Modelling of stage duration by gamma functions for cumulative distributions of stages $\mathrm{VI}_{\mathrm{A} 0}$ $(-), \mathrm{VI}_{\mathrm{A} 1}(-), \mathrm{VI}_{\mathrm{A} 2}(-)$ and $\mathrm{VI}_{\mathrm{A} 3}(-)$ according to pigmentation time (cumulative sum from the beginning of the experiment of the days corrected with the product of an efficient daily temperature and an efficient daily salinity). (b) Correspondence between observed daily temperature and efficient daily temperature (-) and between observed daily salinity and efficient daily salinity (---).

Parameters $\mathrm{p}_{7}$ and $\mathrm{p}_{8}$ corresponding to 'efficient daily salinity' were calculated as $\mathrm{p}_{7}=0.071(0.050-0.092)$ and $\mathrm{p}_{8}=0.456(0.332-0 \cdot 580)$.

\section{MODEL TESTING}

The data provided by the two additional laboratory experiments were fitted by the model. $\mathrm{V}_{1}$ and $\mathrm{V}_{2}$ corresponded to 1230 and 1085 glass eels analysed on three occasions and split into nine cumulated stage values. The calculated $R^{2}$ was 0.97 
and 0.74 and the mean absolute residual was 5 and $12 \% . \mathrm{V}_{3}$ and $\mathrm{V}_{4}$ corresponded each to 300 glass eels analysed on seven occasions and split into 21 cumulated stage values. The calculated $R^{2}$ was 0.93 and 0.86 and the mean absolute residual was 5\% and 10\% (Fig. 3).

\section{STAGE DURATION DERIVED FROM THE MODEL}

The following result describes the model output for stage duration at constant temperature and salinity. In fresh water, the duration from stage $\mathrm{V}_{\mathrm{B}}$ to $\mathrm{VI}_{\mathrm{A} 0}$ would be 20,3 and 2 days for 5, 10 and $15^{\circ} \mathrm{C}$ respectively. From stage $\mathrm{V}_{\mathrm{B}}$ to $\mathrm{VI}_{\mathrm{A} 3}$, these durations would be extended to 240,40 and 20 days. With a salinity of 20 , the durations would be nearly doubled (Fig. 4).

\section{DISCUSSION}

\section{EFFECT OF ENVIRONMENTAL FACTORS ON PIGMENTATION DEVELOPMENT}

Both pigmentation evolution and modelling clearly confirm that temperature was the main factor controlling the dynamics of pigmentation during the in situ stay of glass eel batches, both in the estuarine and in the fluvial sites. This result is in accordance with the other experiments carried out on $A$. anguilla glass eels (Strubberg, 1913; Panu, 1929a; Lecomte-Finiger, 1983; Ciccotti et al., 1993), as well as Anguilla japonica Temminck \& Schlegel (Dou et al., 2003).

(a)

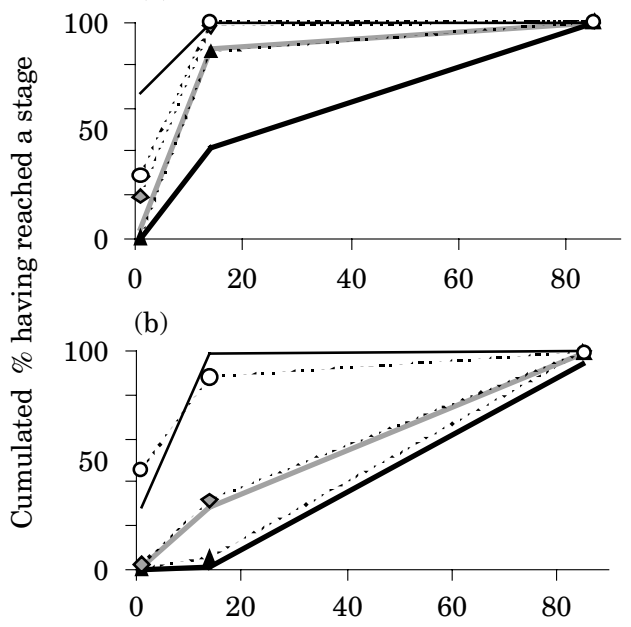

(c)

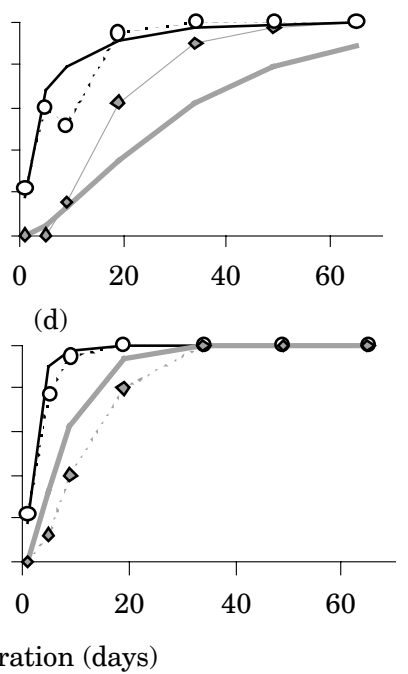

FIG. 3. Validation of the model with glass eels collected elsewhere in Europe, for observed (-○-) and modelled (-) cumulative distributions of stages $\mathrm{VI}_{\mathrm{A} 0}(-; \mathrm{O}), \mathrm{VI}_{\mathrm{A} 2}(-; \diamond)$ and $\mathrm{VI}_{\mathrm{A} 3}(-; \mathbf{\Delta})$. (a) Strubberg (1913) (18 C, salinity 16), (b) Strubberg (1913) (12 ${ }^{\circ}$ C, salinity 16), (c) E. Ciccotti (unpubl. data) $\left(15^{\circ} \mathrm{C}\right.$, salinity 36$)$ and (d) E. Ciccotti (unpubl. data) $\left(15^{\circ} \mathrm{C}\right.$, salinity 0$)$. 


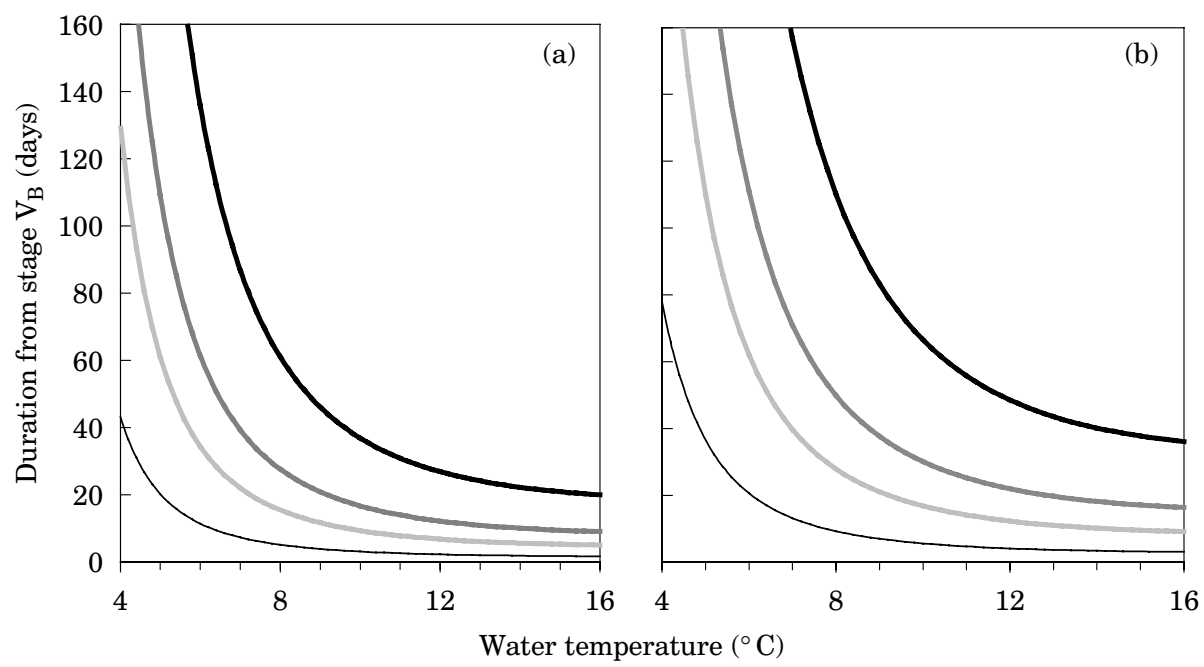

FIG. 4. Stage durations derived from the model. Durations from stage $\mathrm{V}_{\mathrm{B}}$ to $\mathrm{VI}_{\mathrm{A} 0}(-), \mathrm{VI}_{\mathrm{A} 1}(-), \mathrm{VI}_{\mathrm{A} 2}$ (-) and $\mathrm{VI}_{\mathrm{A} 3}$ (一), for salinities of (a) 0 and (b) 20 .

The effect of salinity was less easy to recognize in the natural conditions, because of the continuous tide-related variation of salinity, besides the possibility that the estuarine environment influences pigmentation rates by factors other than salinity. At a general level in the model, however, salinity acted as a secondary factor slowing down pigmentation, and higher salinities, related to estuarine conditions in the in situ experiments, were in fact related to less advanced pigmentation trends (Briand et al., 2004), as also reported by other authors (Panu, 1929b; Lecomte-Finiger, 1983).

Environmental factors such as temperature or salinity influence eel metamorphosis, and related events via the pituary-thyroid axis (Vilter, 1946; Ozaki et al., 2000; Jegstrup \& Rosenkilde, 2003), that controls basic physiological processes, including growth and environmental adaptation. Increased temperatures trigger metamorphosis through thyroid stimulation (Eales, 1985; Leloup \& De Luze, 1985; Eales \& Shostak, 1986; Mellinger, 1994; Power et al., 2001). Temperatures could, however, also directly influence duration of metamorphosis shortening it by an increased metabolic rate (Youson, 1988).

The explanation of the role of salinity is less straightforward. Glass eels maintained in full salinity can develop fully and fresh water is not necessary for the completion of metamorphosis (Schmidt, 1909) as illustrated by the widespread occurrence of glass eels in fully saline conditions (Antunes \& Tesch, 1997) or of yellow eels without a freshwater phase (Tsukamoto et al., 1998; Tzeng et al., 2001; Arai et al., 2003). Acclimation by yellow eels to high salinities induces, as does temperature, significant simulation of thyroid hormone secretion and of peripheral conversion of T4 to T3 (Leloup \& De Luze, 1985). In glass eels, on the other hand, it was shown that the production of a protein containing thyroid hormone levels was twice as high in fresh water than in salt water (Monaco et al., 1981). In both cases, the higher thyroid activity could be the response to the osmoregulatory challenge. 


\section{PIGMENTATION TIME}

The product of the two variables 'efficient daily salinity' and 'efficient daily temperature' takes account of the interacting effect of the two factors, i.e. even if the salinity is favourable, a low temperature will result in a low pigmentation time. The beta function adjusting the temperature effect allows the great variability of speeds of transition between stages to be illustrated. The beta function adjusting the salinity makes it possible to modulate the effect of temperature by a light retarding effect for large salinities [Fig. 2(b)].

The pigmentation time was considered as independent from the individual level, the pigment stage and the experiment. Indeed, the model was not related to the individual level, and the times an individual spends at each stage were independently distributed (Manly, 1990). Although there might be some individual variability in the pigmentation (Schmidt, 1909), the model was adjusted on a modal value calculated on the splitting of a mean number of 63 glass eels in five stages. In practice, stage transition models seldom allow the individual level to be considered (Kempton, 1979).

The model was also considered as independent from pigment stages, in other words the influences of salinity and temperature on the ontogenetic processes were considered the same for all stages. Indeed, the enhancement of the osmoregulatory ability might not be sufficient to exert a large difference from stage $V_{B}$ to stage $\mathrm{VI}_{\mathrm{A} 3}$. For glass eels kept at ambient temperatures ranging from 9 to $18^{\circ} \mathrm{C}$, a significant change in the drinking rate was observed, but only after 3 months in salt water, and 5 months in fresh water (Birrell et al., 2000), that is, for durations longer than the present experiments. Moreover, the development of the oesophagus, an important osmoregulatory organ was shown to be partly independent from pigmentation (Ciccotti et al., 1993). Ontogenetic processes are continuous and 'stage' does not imply an instantaneous state (Youson, 1988). In the case of the transition from glass eel to elver, steps are defined by pigment stages, but these do not give information on the biological or physiological state of a glass eel (Jegstrup \& Rosenkilde, 2003).

Similarly the use of the same pigmentation time for all experiments implies a lesser adjustment than if separate pigmentation times were used for each experiment. This confers, however, predictive capabilities to the model under a wide range of environmental conditions.

\section{PIGMENTATION MODELLING}

In this study the fishing location was in the Vilaine Estuary, $12 \mathrm{~km}$ from the sea. This short distance and the heavy fishing pressure (Briand et al., 2003) resulted in a majority of $\mathrm{V}_{\mathrm{B}}$ and $\mathrm{VI}_{\mathrm{A} 0}$ pigment stages throughout the season (Table II). These conditions helped the building of a model using gamma distributions, because there was a single peak in numbers of glass eels entering the population at time zero (Manly, 1990). The progressive ageing of the sample collected in the estuary from February to April was corrected with the use of an initial pigmentation time calculated from the initial pigment stages composition. A sample consisting of multiple waves of glass eels having entered the estuary (i.e. with several peaks in number entering at time zero) would therefore not have been well described, and 
this may explain the higher mean absolute residuals observed in the validation experiments $\mathrm{V}_{1}$ and $\mathrm{V}_{2}$ (Fig. 3).

The model should be used to describe samples collected in estuaries in winter and springtime with temperatures ranging from 0 to $20^{\circ} \mathrm{C}$. Accordingly, the model should be used for salinities ranging from 0 to 27 . With a salinity of 35 , the validation experiment $\mathrm{V}_{4}$ was out of the model range and had a lesser adjustment (higher mean absolute residual) with an exacerbated slowing down effect (Fig. 3). Other experiments would therefore be needed to analyse pigmentation kinetics in the sea.

Similarly, other experiments would be needed to extend the model to the first stage $\mathrm{V}_{\mathrm{A}}$ whose importance was stressed near the mouth of the estuary (Charlon \& Blanc, 1982) and to the two last and longest stages $\mathrm{VI}_{\mathrm{A} 4}$ and $\mathrm{VI}_{\mathrm{B}}$ (Strubberg, 1913; Ciccotti et al., 1993).

\section{MODEL APPLICATIONS}

The space and time dynamics of the glass eels migration in a given site results from three different interacting features. The first feature is inherent to the overall composition of the glass eel cohort, that depends on the developmental stage as well as on the physiological state of the single individuals (Boëtius \& Boëtius, 1989; Désaunay \& Guérault, 1997). De Casamajor et al. (2001b) did not observe any significant difference in the quality and physiological state of successive runs of unpigmented glass eels arriving at the Biscay Bay coast in the course of a season. Therefore it is possibly that the timing of arrival near the coast mostly determines the variation in the estuarine sojourn, mirrored in the developmental level and hence in the pigmentation stages of the glass eel groups collected in the estuary (Jellyman et al., 1999; De Casamajor et al., 2001a).

The second and strongest factor is extrinsic, and is represented by the hydrological dynamics of the water masses in the estuary, that drives the upstream transport of glass eels when they are in their passive phase and facilitate or oppose their active swimming performances when in the colonization stage (Gascuel, 1986; McCleave \& Wippelhauser, 1987). As a consequence, the same glass eel cohort can evolve in different pigmentation clusters if the migratory shoal breaks up in relation to unfavourable hydrological conditions in the estuary (Elie \& Rochard, 1994; De Casamajor et al., 2000).

At a third level, the single estuarine abiotic conditions (e.g. temperature, salinity variations turbidity and current speed) influence the individuals, in that they affect their specific developmental pace but also because they might condition their individual response to environmental stimuli (Edeline et al., 2004).

On the whole, most authors unanimously report a major time frequency, i.e. a 2 week cycle of the waves of invasion of glass eels. This periodicity of ascent is evident from abundance trends in most estuaries (Jellyman, 1979; Sorensen \& Bianchini, 1986; Ciccotti et al., 1995) as well as from the pigmentation frequency composition of glass eel samples (Elie, 1979; Boëtius \& Boëtius, 1989). This periodicity in the peaks of abundance and in the glass eels pigmentation composition can change or level out in relation to abnormalities in the migration progress such as quantitative reductions, ecological disturbances or fishing pressure. 
Within an estuary, the timing of arrival will determine the temporal variation in recruitment strength; hydrological factors will modulate the spatial and temporal dynamic of migration, while abiotic factors will determine pigment stage evolution, which could also be related to behavioural response such as settlement. Monitoring of temperatures and salinities allows the evolution of pigment stages of a sample collected at one place in the estuary and at repeated intervals to be modelled. For each stage, it is possible to add the pigmentation time necessary to reach this stage to the pigmentation time corresponding to the temperatures and salinities recorded between each sampling date, and predict a change in pigment stages. The difference between predicted and observed values provides an idea for the net increase or decrease for each stage. Theses variations are the consequence of recruitment, migration, mortality and settlement processes that could in turn be modelled, and fitted on the data.

The seasonal variation of pigment stages would then provide an ecological descriptor of the migration course allowing fast and affordable monitoring of the waves of glass eels entering the estuary. It could therefore be used in field studies, as the tool to trace out the migratory pattern, but also describe the anthropogenic pressures applied to glass eels. For instance, for glass eel fisheries, pigment stage collected at different space and time could be included in a model used to predict and post-evaluate the effect of fishing regulations.

We would like to thank R. Poole for correcting the manuscript.

\section{References}

Antunes, C. \& Tesch, F. W. (1997). Eel larvae (Anguilla anguilla L.) caught by R. V. "Heincke" at the European continent slope in autumn 1991. Ecology of Freshwater Fish 6, 50-52.

Arai, T., Otake, T. \& Tsukamoto, K. (1997). Drastic change in otolith microstructure and microchemistry accompanying the onset of metamorphosis in the Japanese eel Anguilla japonica. Marine Ecology Progress Series 161, 17-22.

Arai, T., Kotake, A., Ohji, M., Miller, M. J., Tsukamoto, K. \& Miyazaki, N. (2003). Occurrence of sea eels of Anguilla japonica along the Sanriku Coast of Japan. Ichthyological Research 50, 78-81.

Bertin, L. (1951). Les anguilles. Variation, croissance, euryhalinité, toxicité, hermaphrodisme juvénile et sexualité, migrations, métamorphoses. Paris: Payot.

Birrell, L., Cramb, G. \& Hazon, N. (2000). Osmoregulation during the development of glass eels and elvers. Journal of Fish Biology 56, 1450-1459. doi: 10.1006/ jfbi.2000.1271

Bishop, R. E. \& Torres, J. J. (2001). Leptocephalus energetics: assembly of the energetic equation. Marine Biology 138, 1093-1098.

Bishop, R. E., Torres, J. J. \& Crabtree, R. E. (2000). Chemical composition and growth indices in leptocephalus larvae. Marine Biology 137, 205-214.

Boëtius, I. \& Boëtius, J. (1989). Ascending elvers, Anguilla anguilla, from five European localities. Analyses of pigmentation stages, condition, chemical composition and energy reserves. Dana 7, 1-12.

Boëtius, J. (1976). Elvers, Anguilla anguilla and Anguilla rostrata from two Danish localities. Size, body weight, developmental stage and number of vertebrae related to the time of ascent. Meddelester fra Danmarks Fiskeri- og Havundersøgesler 7, 199-220.

Briand, C., Fatin, D., Feunteun, E. \& Fontenelle, G. (2003). Estuarine and fluvial recruitment of European glass eel in a fished Atlantic estuary. Fisheries Management and Ecology 10, 377-384. 
Briand, C., Fatin, D. \& Lambert, P. (2004). Effets de la salinité et de la température sur la cinétique de pigmentation des civelles (Anguilla anguilla). Cybium 28, 247-254.

Cantrelle, I. (1981). Etude de la migration et de la pêche des civelles (A. anguilla L. 1758) dans l'estuaire de la Gironde. PhD Thesis, Université Paris VI, Paris.

Castle, P. H. J. (1997). Garden eel leptocephali: character, generic identification, distribution, and relationship. Bulletin of Marine Science 60, 6-22.

Charlon, N. \& Blanc, J. M. (1982). Etude des civelles d'Anguilla anguilla L. dans la région du bassin de l'Adour. 1. Caractéristiques biométriques de longueur et de poids en fonction de la pigmentation. Archiv für Hydrobiologie 93, 238-255.

Ciccotti, E., Macchi, E., Rossi, A., Cataldi, E. \& Cataudella, S. (1993). Glass eel (Anguilla anguilla) acclimatation to freshwater and seawater: morphological changes of the digestive track. Journal of Applied Ichtology 9, 74-81.

Ciccotti, E., Ricci, T., Scardi, M., Fresi, E. \& Cataudella, S. (1995). Intraseasonal characterization of glass eel migration in the River Tiber: space and time dynamics. Journal of Fish Biology 47, 248-255.

Cieri, M. D. (1999). Migration, growth, and early life history of the American eel (Anguilla rostrata). PhD Thesis, University of Maine.

Creutzberg, F. (1958). Use of tidal streams by migrating elvers (Anguilla vulgaris, Turt.). Nature 181, 857-858.

De Casamajor, M. N. (1998). Comportement migratoire de la civelle d'anguille (Anguilla anguilla $\mathrm{L}$.) dans l'estuaire de l'Adour en fonction de la variabilité des conditions environnementales. PhD Thesis, Université de Pau et des pays de l'Adour, Paris, France.

De Casamajor, M. N., Prouzet, P. \& Lazure, P. (2000). Identification des flux de civelles (Anguilla anguilla) à partir des relations d'allométrie en fonction des conditions hydrodynamiques de l'estuaire de l'Adour. Aquatic Living Resources 13, 411-420.

De Casamajor, M. N., Lecomte-Finiger, R. \& Prouzet, P. (2001a). Passé larvaire des civelles, Anguilla anguilla, (Linné, 1758) en migration en zones côtière et estuarienne (Adour, Golfe de Gascogne) à partir de l'examen des otolithes. Comptes Rendus de l'Académie des Sciences, Paris 324, 1011-1019.

De Casamajor, M. N., Lecomte-Finiger, R. \& Prouzet, P. (2001b). Détermination de l'état d'amaigrissement des civelles (Anguilla anguilla) en migration en zone côtière et estuarienne. Comptes Rendus de l'Académie des Sciences, Paris 324, 345-353.

De Casamajor, M. N., Lecomte-Finiger, R. \& Prouzet, P. (2003). Caractéristiques biologiques des civelles (Anguilla anguilla) lors de la transition en estuaire. Bulletin Francais de la Pêche et de la Pisciculture 368, 109-124.

Désaunay, Y. \& Guérault, D. (1997). Seasonal and long-term changes in biometrics of eel larvae: a possible relationship between recruitment variation and North Atlantic ecosystems productivity. Journal of Fish Biology 51, 317-339.

Dou, S., Miller, M. J. \& Tsukamoto, K. (2003). Growth, pigmentation and activity of juvenile Japanese eels in relation to temperature and fish size. Journal of Fish Biology 63, 152-165. doi: 10.1111/j.1095-8649.2003.00211.x

Eales, J. G. (1985). The peripheral metabolism of thyroid hormones and regulation of thyroidal status in poikilotherms. Canadian Journal of Zoology 63, 1217-1231.

Eales, J. G. \& Shostak, S. (1986). Influences of temperature and $\mathrm{pH}$ on free T4 and free T3 in charr and trout plasma. General and Comparative Endocrinology 61, 272-277.

Edeline, E., Dufour, S., Briand, C., Fatin, D. \& Elie, P. (2004). Thyroidal status is related to migratory behavior in glass eels of Anguilla anguilla. Marine Ecology Progress Series 282, 261-270.

Elie, P. (1979). Contribution à l'étude des montées de civelles d' Anguilla anguilla L. (poisson téléostéen anguilliforme) dans l'estuaire de la Loire: pêche, écologie, écophysiologie et élevage. PhD Thesis, Université de Rennes, France.

Elie, P. \& Daguzan, J. (1976). Alimentation et croissance des civelles d'Anguilla anguilla (poisson téléosteen anguilliforme) élevées expérimentalement a diverses températures au laboratoire. Annales de la Nutrition et de l'Alimentation 30, 229-244. 
Elie, P. \& Rochard, E. (1994). Migration des civelles d'anguilles (Anguilla anguilla L.) dans les estuaires, modalités du phénomène et caractéristiques des individus. Bulletin Français de la Pêche et de la Pisciculture 335, 81-98.

Elie, P., Lecomte-Finiger, R., Cantrelle, I. \& Charlon, N. (1982). Définition des limites des différents stades pigmentaires durant la phase civelle d'Anguilla anguilla L. Vie et Milieu 32, 149-157.

Gascuel, D. (1986). Flow carried and swimming migration of the glass eel (Anguilla anguilla) in the tidal area of a small estuary on the French Atlantic coast. Helgoländer Meeresuntersuchungen 40, 321-326.

Haro, A. \& Krueger, W. H. (1988). Pigmentation, size, and migration of elvers (Anguilla rostrata, Lesueur) in a coastal Rhode Island stream. Canadian Journal of Zoology 66, 2528-2533.

Hickman, R. A. (1981). Densities and swimbladder development of juvenile American eels Anguilla rostrata (Le Sueur) as related to energetics of migration. Journal of Fish Biology 18, 507-517.

Hulet, W. H. (1978). Structure and functional development of the eel leptocephalus Ariosoma balearicum (de la roche, 1809). Philosophical Transaction of the Royal Society London 282, 107-138.

Hulet, W. H. \& Robins, R. (1989). The evolutionary significance of the leptocephalus larvae. In Fishes of the Western North Atlantic, Vol. 2 (part 9) (Böhlke, E. A., ed.), pp. 669-679. New Haven, CT: Sears Foundation for Marine Research.

Jegstrup, I. M. \& Rosenkilde, P. (2003). Regulation of post-larval development in the European eel: thyroid hormone level, progress of pigmentation and changes in behaviour. Journal of Fish Biology 63, 168-175. doi: 10.1046/j.10958649.2003.00138.x

Jellyman, D. J. (1979). Upstream migration of glass eel (Anguilla sp.) in the Waikato river. New Zealand Journal of Marine and Freshwater Research 13, 13-22.

Jellyman, D. J., Chisnall, B. L., Bonnett, M. L. \& Sykes, J. R. E. (1999). Seasonal arrival patterns of juvenile freshwater eels (Anguilla spp.) in New Zealand. New Zealand Journal of Marine and Freshwater Research 33, 249-261.

Kawakami, Y., Mochioka, N., Kimura, R. \& Nakazono, A. (1999). Seasonal changes of the RNA/DNA ratio, size and lipid content and migration adaptability of Japanese glass-eels, Anguilla japonica, collected in northern Kyushu, Japan. Journal of Experimental Marine Biology and Ecology 238, 1-19.

Kempton, R. A. (1979). Statistical analysis of frequency data obtained from sampling an insect population grouped by stages. In Statistical Distributions in Scientific Work (Ord, J. K., Patil, G. P. \& Taillie, C., eds), pp. 401-418. Fairland, MD: International Cooperative Publishing House.

Lecomte-Finiger, R. (1983). Contribution à la connaissance de l'écobiologie de l'anguille, Anguilla anguilla, L. 1758, des milieux lagunaires méditerranéens du golfe du Lion: Narbonnais et Roussillon. PhD Thesis, Université de Perpignan, France.

Leloup, J. \& De Luze, A. (1985). Environmental effects of temperature and salinity on thyroid function in Teleost fishes. In The Endocrine System and the Environment (Follet, B. K., Ishii, S. \& Chandola, A., eds), pp. 23-32. Tokyo: Japan Scientific Society Press.

Manly, B. F. J. (1990). Stage Structured Populations (Usher, M. B., ed.). London: Chapman \& Hall.

Martin, M. H. (1995). The effects of temperature, river flow, and tidal cycles on the onset of glass eel and elver migration into fresh water in the American eel. Journal of Fish Biology 46, 891-902.

McCleave, J. D. \& Wippelhauser, G. (1987). Behavioral aspects of selective tidal stream transport in juvenile American eel. American Fisheries Society Symposium 1, $138-150$.

Mellinger, J. (1994). Le rôle des hormones thyroïdiennes dans le développement des poissons. Bulletin de la Société Zoologique de France 119, 315-324.

Monaco, F., Roche, J., Carducci, C., Carlini, F., Cataudella, S., Felli, P., Andreoli, M. \& Dominici, R. (1981). Influence du changement d'habitat (eau de mer et eau douce) 
sur la biosynthèse de la thyroglobuline in vivo chez des civelles d'anguilles atlantiques, Anguilla anguilla L. Compte Rendu Séances Société de Biologie et de ses Filiales 175, 452-456.

Ozaki, Y., Okumura, H., Kazeto, Y., Ikeuchi, T., Ijiri, S., Nagae, M., Adachi, S. \& Yamauchi, K. (2000). Developmental change in pituitary-thyroid axis, and formation of gonads in leptocephali and glass eels of anguilla spp. Fisheries Science 66, 1115-1122.

Pankhurst, N. W. (1983). Retinal development in larval and juvenile European eel, Anguilla anguilla (L.). Canadian Journal of Zoology 62, 335-343.

Panu, A. (1929a). Les pigments du tégument de l'anguille. Etude morphologique et biologique. PhD Thesis, Faculté des sciences de Paris, Paris.

Panu, A. (1929b). Sur l'influence des caractères physico-chimiques du milieu sur l'évolution du pigment et l'état physiologique de l'anguille. Comptes Rendus de la Société Biologique 101, 279-281.

Pfeiler, E. (1999). Developmental physiology of elopomorph leptocephali. Comparative Biochemistry and Physiology Part A 123, 113-128.

Power, D. M., Llewellyn, L., Faustino, M., Nowell, M. A., Björnsson, B. T., Einarsdottir, I. E., Canario, A. V. M. \& Sweeney, G. E. (2001). Thyroid hormones in growth and development of fish. Comparative Biochemistry and Physiology $C$ 130, 447-459.

Robins, C. R. (1989). The phylogenetic relationship of the anguilliform fishes. In Fishes of the Western North Atlantic, Vol. 2 (part 9) (Böhlke, E. A., ed.), pp. 9-23. New Haven, CT: Sears Foundation for Marine Research.

Sadler, K. (1979). Effect of temperature on the growth and survival of the European eel, Anguilla anguilla L. Journal of Fish Biology 15, 499-507.

Schmidt, J. (1909). Remarks on the metamorphosis and distribution of the larvae of the eel (Anguilla vulgaris, Turt.). Meddelester fra Kommissionen for Havundersøgesler, serie Fiskeri Copenhagen III, 1-17.

Smith, D. G. (1989). Introduction to leptocephali. In Fishes of the Western North Atlantic, Vol. 2 (part 9): Leptocephali (Böhlke, E. A., ed.), pp. 657-677. New Haven, CT: Sears Foundation for Marine Research.

Sorensen, P. W. \& Bianchini, M. L. (1986). Environmental correlates of the freshwater migration of elvers of the American eel in a Rhode Island brook. Transactions of the American Fisheries Society 115, 258-268.

Strubberg, A. C. (1913). The metamorphosis of elvers as influenced by outward conditions. Meddelester fra Kommissionen for Havundersøgesler, serie Fiskeri Copenhagen 4, 1-11.

Tesch, F. W. (1980). Occurrence of eel Anguilla anguilla larvae west of the European continental shelf, 1971-1977. Environmental Biology of Fishes 5, 185-190.

Tesch, F.-W. (2003). The Eel (Thorpe, J. E., ed.), 3rd edn. London: Blackwell Publishing.

Tsukamoto, K. (1990). Recruitment mechanism of the eel, Anguilla japonica, to the Japanese coast. Journal of Fish Biology 36, 659-671.

Tsukamoto, K., Nakai, I. \& Tesch, F. W. (1998). Do all freshwater eels migrate? Nature 396, 635 .

Tzeng, W. N. \& Tsai, Y. C. (1994). Change in otolith microchemistry of the Japanese eel Anguilla japonica, during its migration from the ocean to the rivers of Taiwan. Journal of Fish Biology 45, 671-683.

Tzeng, W. N., Wang, C. H., Wickström, H. \& Reizenstein, M. (2001). Occurence of the semi-catadromous European eel Anguilla anguilla in the Baltic sea. Marine Biology 137, 93-98.

Vilter, V. (1946). Action de la Thyroxine sur la métamorphose larvaire de l'anguille. Comptes Rendus de la Société Biologique 140, 783-785.

Youson, J. H. (1988). First metamorphosis. In Fish Physiology, Vol. XIB (Hoar, W. S. \& Randall, D. J., eds), pp. 135-196. New York: Academic Press. 